\title{
Screening, Isolation, Identification and Antibiogram Study of Enterobacteriaceae in Ready to Cook, Chilled Food Products in Tiruchirappalli, India
}

\author{
Antony Jenifer (D) and Karupannan Sathiyamurthy* (iD \\ Department of Biomedical Science, School of Biotechnology and Genetic Engineering, Bharathidasan \\ University, Tiruchirappalli - 620024. Tamil Nadu, India.
}

\begin{abstract}
The present study was concentrated to screen some members in Enterobacteriaceae family from chilled meat products procured from different retail shops in Tiruchirappalli, Tamilnadu. A total of six varieties of ready to cook chilled food products with five samples in each were randomly purchased from departmental stores, retailer meat shops and local vendors of Tiruchirappalli. Out of $\mathbf{3 0}$ ready to cook, chilled food products screened for the presence of Enterobacteriaceae, 28 found to be positive for Enterobacteriaceae. A total of $\mathbf{3 6}$ bacterial strains were selected at random and identified. Only 11 isolates were finally confirmed as Enterobacteriaceae and this was shared by Escherichia coli (E. coli), Citrobacter spp., Salmonella spp., Serratia spp. and Proteus spp. Among these Proteus spp. (23.3\%) was found predominant in all the samples. Antibiogram study revealed that $54.5 \%$ isolates were susceptible to each of Ofloxacin and Ciprofloxacin followed by Ampicillin (45.5\%), Chloramphenicol (27.3\%) and Gentamycin (18.2\%). A high percentage of $54.5 \%$ isolates were found to be multidrug resistance (resistant to 3 or more antibiotics). E. coli and Proteus spp. isolated from mixed vegetables and beef respectively, were exhibited $\mathbf{1 0 0 \%}$ resistant to Penicillin, Ciprofloxacin, Chloramphenicol, Ofloxacin, Ampicillin and Gentamycin. The study revealed poor sanitation and cross-contamination in food processing area which resulted in the enhancement of enteropathogenic bacteria which are, known to cause foodborne illnesses. Also, the multidrug resistance noticed in the present study may be linked to the use of antibiotics in cattle rearing which constitute a serious threat to public health.
\end{abstract}

Keywords: Ready to cook, Enterobacteriaceae, Antibiogram, Sanitation, Foodborne illness, Cross-contamination

*Correspondence: ksathiyamurthy@yahoo.com; +91-9444581708

(Received: April 27, 2020; accepted: May 26, 2020)

Citation: Jenifer A, Sathiyamurthy K. Screening, Isolation, Identification and Antibiogram Study of Enterobacteriaceae in Ready to Cook, Chilled Food Products in Tiruchirappalli, India. J Pure Appl Microbiol. 2020;14(2):1513-1518. doi: 10.22207/JPAM.14.2.49

C The Author(s) 2020. Open Access. This article is distributed under the terms of the Creative Commons Attribution 4.0 International License which permits unrestricted use, sharing, distribution, and reproduction in any medium, provided you give appropriate credit to the original author(s) and the source, provide a link to the Creative Commons license, and indicate if changes were made. 


\section{INTRODUCTION}

The emergence of multidrug resistant bacteria has been reported worldwide and it is a major public health concern ${ }^{1}$. The most important gram-negative bacteria found in the intestinal tract belong to the family Enterobacteriaceae is the challengeable contaminants in raw and cooked food products ${ }^{2}$. Coliforms are indicators of faecal contamination in food ${ }^{3}$. Enterobacteriaceae in ready to cook food products causes foodborne illness associated with mild to severe diarrhoea due to gastrointestinal disorders and clinical manifestations in human ${ }^{4}$. Enterobacteriaceae such as E. coli and Salmonella species are most predominant in some meat products ${ }^{5,6}$. E. coli are considered as a sepathogenic, non-pathogenic and commensal organism found in the intestinal region of both animal and human ${ }^{7}$. Salmonella is the predominant foodborne pathogen causing salmonellosis due to the consumption of undercooked meat and eggs ${ }^{8}$.

Worldwide, 2.2 million adults and children under five years of age die of diarrhoeal disease every year from foodborne and waterborne illnesses. In developing countries, the major cause of foodborne infections is the cross-contamination of meat and raw vegetables by polluted water, soil, air and unhygienic handling. The major factors which affect the quality of perishable foods are microbes present within the animal before slaughtering, enzymatic changes and external sources during processing, microbial accumulation after slaughtering within the tissues, time and temperature of storage, handling at the distribution center ${ }^{9}$. In general, the rate of deterioration is higher in seafoods because of decay organisms present in their gastrointestinal system which rapidly multiply after death ${ }^{10}$. Nowadays, due to lifestyle modernization and raised standard of living, the consumption of ready to cook fresh slaughtered chilled meat, seafoods and vegetable products have increased in India ${ }^{11,12}$. Therefore, the present study was planned to determine the presence of members of Enterobacteriaceae and to study the antimicrobial resistance of isolated gram-negative bacteria in different ready to cook foods obtained in Tiruchirappalli, Tamilnadu.

\section{MATERIALS AND METHODS}

The isolation of members of
Enterobacteriaceae was carried out as per The United States - Food and Drug Administration (US-FDA) bacteriological manual $8^{\text {th }}$ edition with slight modification ${ }^{13}$.

\section{Media preparation}

All the media used in the study were prepared according to the manufacturer's instructions.

\section{Sample Collection}

A total of six different chilled ready to cook food products with five samples in each such as raw meat samples (chicken, pork and beef meat), seafood samples (fish and prawns) and mixed vegetables were purchased at random from local vendors, departmental stores and local meat retailers located in Tiruchirappalli, Tamilnadu. The samples were transported immediately to the laboratory for microbial evaluation under the packaging condition provided by the retailers and stored under same condition until analysis.

\section{Sample Preparation}

Twenty-five grams of all chilled ready to cook samples were finely chopped with a sterile knife and transferred to $225 \mathrm{ml}$ of 10x Phosphate Buffer Solution (PBS) and incubated for $24 \mathrm{~h}$ at $37^{\circ} \mathrm{C}$ for pre-enrichment. The enrichment process was done by transferring $1 \mathrm{ml}$ of pre-enriched broth to $9 \mathrm{ml}$ of Lactose broth, Selenite $\mathrm{F}$ broth and Tetrathionate broth (Himedia, Mumbai) and incubated at $37^{\circ} \mathrm{C}$ for $24 \mathrm{~h}$. A loop full of each enriched broth was streaked on to MacConkey agar plates and Xylose Lysine Deoxycholate (XLD) agar plates (Himedia, Mumbai) in triplicates. The probable morphologically distinct colonies were picked up and streaked on to nutrient agar media (Himedia, Mumbai) and incubated at $37^{\circ} \mathrm{C}$ for $24 \mathrm{~h}$. Then the pure colonies were subjected to various biochemical analysis for identification.

\section{Identification of Isolated Bacteria}

The isolated bacteria were identified using colony morphology and biochemical tests $^{14,15}$. E. coli colonies were further re-streaked on Eosin Methylene Blue agar (EMB) (Himedia, Mumbai) and incubated at $37^{\circ} \mathrm{C}$ for $24 \mathrm{~h}$ for reconfirmation. Colonies with a green metallic sheen were confirmed as E. coli. Black colonies on XLD agar plates were further tested with urease broth. The urease positive was confirmed to be Proteus sp. and Salmonella sp. was confirmed by the $\mathrm{H}_{2} \mathrm{~S}$ formation in Triple Sugar Iron (TSI) agar 
and negative urease tests. The production of red prodigiosin pigment in nutrient agar confirmed the presence of Serratia sp. Citrobacter sp. was confirmed by colony morphology and other biochemical tests such as Indole, Methyl Red, Voges-Proskauer, Citrate (IMViC), Lysin Iron Agar (LIA), Motility Indole Ornithine (MIO), Oxidase, Catalase, Extracellular enzymatic activities test such as Amylase, Protease and Lipase. Oxidative Fermentative test using OF media and carbohydrate fermentation test using Phenol Red Broth (PRB) (Himedia, Mumbai) were performed with glucose and sucrose.

\section{Antibiotic susceptibility test}

The antibiotic sensitivity test was performed against isolated colonies by KirbyBauer disc diffusion method as described by CLSI standard guidelines ${ }^{16}$. The antibiotics used were Penicillin (P, 10 units), Ciprofloxacin (CIP, $5 \mathrm{mcg}$ ), Gentamycin (GEN, $10 \mathrm{mcg}$ ), Ofloxacin (OF, $5 \mathrm{mcg}$ ), Chloramphenicol (C, $30 \mathrm{mcg}$ ) and Ampicillin (AMP, $10 \mathrm{mcg})$. The $24 \mathrm{~h}$ fresh culture of isolated gramnegative bacteria was streaked on to Nutrient Agar (NA) plates and incubated at $37^{\circ} \mathrm{C}$ for $18-20 \mathrm{~h}$. The isolated single colony of all bacterial cultures were inoculated into the nutrient broth and incubated for $4 \mathrm{~h}$ at $37^{\circ} \mathrm{C}$ until the appearance of moderate

Table 1. Different members of Enterobacteriaceae family isolated from ready to cook chilled food samples

\begin{tabular}{|c|c|c|c|c|c|c|c|c|c|}
\hline Samples & $\begin{array}{c}\text { Total } \\
\text { no. of } \\
\text { samples }\end{array}$ & $\begin{array}{l}\text { Total no. } \\
\text { of positive } \\
\text { samples }\end{array}$ & $\begin{array}{l}\text { Total no. of } \\
\text { suspected } \\
\text { isolates }\end{array}$ & $\begin{array}{l}\text { Total no. } \\
\text { of typical } \\
\text { isolates }\end{array}$ & $\begin{array}{c}E . \\
\text { coli }\end{array}$ & $\begin{array}{c}\text { Citrobacter } \\
\text { sp. }\end{array}$ & $\begin{array}{l}\text { Proteus } \\
\text { sp. }\end{array}$ & $\begin{array}{c}\text { Salmonella } \\
\text { sp. }\end{array}$ & $\begin{array}{c}\text { Serratia } \\
\text { sp. }\end{array}$ \\
\hline Mixed veg & 5 & 3 & 3 & 1 & 1 & 0 & 0 & 0 & 0 \\
\hline Chicken & 5 & 5 & 6 & 2 & 0 & 0 & 1 & 1 & 0 \\
\hline Beef & 5 & 5 & 10 & 3 & 0 & 1 & 1 & 0 & 1 \\
\hline Pork & 5 & 5 & 5 & 3 & 0 & 0 & 3 & 0 & 0 \\
\hline Fish & 5 & 5 & 6 & 1 & 0 & 0 & 1 & 0 & 0 \\
\hline Prawn & 5 & 5 & 6 & 1 & 0 & 0 & 1 & 0 & 0 \\
\hline Total & 30 & 28 & 36 & $\begin{array}{c}11 \\
(36.6 \%)\end{array}$ & $\begin{array}{c}1 \\
(3.3 \%)\end{array}$ & $\begin{array}{c}1 \\
(3.3 \%)\end{array}$ & $\begin{array}{c}7 \\
(23.3 \%)\end{array}$ & $\begin{array}{c}1 \\
(3.3 \%)\end{array}$ & $\begin{array}{c}1 \\
(3.3 \%)\end{array}$ \\
\hline
\end{tabular}

Table 2. Antimicrobial susceptibility of isolated bacteria against different antibiotics

\begin{tabular}{|c|c|c|c|c|c|c|c|c|}
\hline \multirow[t]{2}{*}{ No. } & \multirow{2}{*}{$\begin{array}{l}\text { Identified } \\
\text { species }\end{array}$} & \multicolumn{6}{|c|}{ Name of the Antibiotics } & \multirow{2}{*}{$\begin{array}{l}\text { Overall } \\
\text { percentage } \\
\text { of antibiotic } \\
\text { resistance }\end{array}$} \\
\hline & & $\mathrm{P}$ & CIP & GEN & OF & C & AMP & \\
\hline 1 & E. coli & $\mathrm{R}$ & $\mathrm{R}$ & $\mathrm{R}$ & $\mathrm{R}$ & $\mathrm{R}$ & $\mathrm{R}$ & 100 \\
\hline 2 & Citrobacter sp. & $\mathrm{R}$ & $\mathrm{S}$ & $\mathrm{S}$ & $\mathrm{S}$ & I & $\mathrm{R}$ & 33.3 \\
\hline 3 & Proteus sp. & $\mathrm{R}$ & $S$ & $\mathrm{R}$ & $\mathrm{S}$ & $\mathrm{R}$ & $\mathrm{R}$ & 66.6 \\
\hline 4 & Proteus sp. & $\mathrm{R}$ & $\mathrm{R}$ & $\mathrm{R}$ & $\mathrm{R}$ & I & $\mathrm{S}$ & 66.6 \\
\hline 5 & Proteus sp. & $\mathrm{R}$ & $\mathrm{R}$ & $\mathrm{R}$ & $\mathrm{S}$ & I & $S$ & 50 \\
\hline 6 & Proteus sp. & $\mathrm{R}$ & $\mathrm{S}$ & $\mathrm{R}$ & $\mathrm{S}$ & I & $\mathrm{S}$ & 33.3 \\
\hline 7 & Proteus sp. & $\mathrm{R}$ & $\mathrm{S}$ & 1 & $S$ & I & $\mathrm{R}$ & 33.3 \\
\hline 8 & Proteus sp. & $\mathrm{R}$ & $\mathrm{R}$ & $\mathrm{R}$ & $\mathrm{R}$ & $\mathrm{R}$ & $\mathrm{R}$ & 100 \\
\hline 9 & Proteus sp. & $\mathrm{R}$ & $S$ & $\mathrm{R}$ & I & $\mathrm{S}$ & $\mathrm{S}$ & 33.3 \\
\hline 10 & Salmonella sp. & $\mathrm{R}$ & $\mathrm{S}$ & $\mathrm{R}$ & $\mathrm{S}$ & $\mathrm{S}$ & $\mathrm{R}$ & 50 \\
\hline 11 & Serratia sp. & $\mathrm{R}$ & 1 & $S$ & 1 & $\mathrm{~S}$ & $S$ & 16.6 \\
\hline
\end{tabular}

The overall Multidrug resistance was found to be 6 out of 11 isolates with $54.5 \%$

(S-Susceptible, I-Intermediate, R-Resistant, P-Penicillin, CIP-Ciprofloxacin, GEN-Gentamycin, OF-Ofloxacin, C-Chloramphenicol, AMP-Ampicillin) 
turbidity. Then the bacterial growth as measured by optical density $\left(O D_{600}\right)$ and adjusted. With the sterile wooden swab sticks the bacterial culture was swabbed on $4 \mathrm{~mm}$ depth Muller Hinton agar (Himedia, Mumbai) and incubated for $24 \mathrm{~h}$ at $37^{\circ} \mathrm{C}$ with antibiotics discs.

\section{RESULTS}

In the present study, 30 ready to cook chilled raw food samples were collected and tested for the presence of members of Enterobacteriaceae bacteria. It was found that only 28 samples showed positive. Among 28 samples, 36 suspected strains were isolated and only 11 (36.6\%) bacterial isolates were confirmed to be that of Enterobacteriaceae (Table 1). The biochemical tests revealed the presence of five pathogenic bacterial isolates viz. E. coli, Citrobacter sp., Salmonella sp., Serratia sp. and Proteus sp. Proteus sp. was the most predominant bacteria in all the chilled meat (chicken, beef, pork) and seafood products (fish, prawn). Salmonella sp. and Proteus sp. were recovered from ready to cook chicken sample. From ready to cook chilled beef sample, Citrobacter sp., Serratia sp. and Proteus sp. were isolated. It was found that minimally processed or unprocessed chilled ready to cook food samples were highly contaminated with Enterobacteriaceae. The antimicrobial susceptibility study indicated the resistance of all isolates to penicillin (100\%) followed by $72.7 \%$ of the isolates to Gentamycin, $54.4 \%$ to Ampicillin, $36.4 \%$ to Ciprofloxacin, and $27.2 \%$ each to Ofloxacin and Chloramphenicol. The gramnegative bacteria of $E$. coli and Proteus sp. isolated from chilled ready to cook mixed vegetables and

Table 3. Percentage of isolated bacterial antibiogram profile

\begin{tabular}{|c|c|c|c|}
\hline $\begin{array}{l}\text { Antibiotics } \\
\text { name }\end{array}$ & Sensitive & $\begin{array}{l}\text { Inter- } \\
\text { mediate }\end{array}$ & Resistant \\
\hline Penicillin & 0 & 0 & 100 \\
\hline Ciprofloxacin & 54.5 & 9.1 & 36.4 \\
\hline Gentamycin & 18.2 & 9.1 & 72.7 \\
\hline Ofloxacin & 54.5 & 18.2 & 27.3 \\
\hline $\begin{array}{l}\text { Chloram- } \\
\text { phenicol }\end{array}$ & 27.3 & 45.5 & 27.3 \\
\hline Ampicillin & 45.5 & 0 & 54.5 \\
\hline Overall & 33.3 & 13.7 & 53 \\
\hline
\end{tabular}

beef samples have shown $100 \%$ resistance to all the six antibiotics used in this study. 54.5\% of bacterial isolates were found to be multidrug resistance (resistant to 3 or more antibiotics) (Table 2). All the isolated 5 species were found susceptible to Ofloxacin (54.5\%), Ciprofloxacin (54.5\%), Ampicillin (45.5\%), Chloramphenicol (27.3\%) and Gentamycin (18.2\%). As a result, the isolates were highly susceptible to Ofloxacin and Ciprofloxacin (54.5\%) and highly resistant to Penicillin (100\%) followed by Ampicillin (54.5\%) (Table 3).

\section{DISCUSSION}

A total of 11 strains were isolated from 28 ready to cook, chilled samples. The occurrence of high Enterobacteriaceae count indicated that there was poor sanitation during slaughtering, storage and hygienic condition inside the butcher's shop which became good sources of crosscontamination from knife, cloth and processing area. Vegetables might get contaminated from manure, water and handling. Hence, this study has clearly shown that the occurrence of different members of Enterobacteriaceae species were common in chilled vegetables and retail meat. In this study, Proteus sp. was present in all the chilled meat and sea food samples with an incidence of $23.3 \%$ and is the most predominant strain isolated from chicken, beef, pork, fish and prawn. The predominance of Proteus sp. might be due to cross-contamination by food handlers while removing intestinal content by hands. It is important to wash their hands after processing any food materials to prevent cross-contamination due to the rapid proliferation of the pathogen. In Tiruchirappalli, seafoods are transported from various places of Tamilnadu. The collected sea food samples were observed to be in broken packages. Also, it was suspected to be contaminated by water and the quality of ice used during transportation. Proteus sp. is considered as an indicator of meat contamination during processing. Many researchers have isolated Proteus sp. from different food samples ${ }^{17-19}$. In addition, Proteus sp. has been proved to cause urinary tract infection and diarrhoea ${ }^{20}$. E. coli contamination was prevalent among vegetables. The frequency of $E$. coli in vegetables was found to be high. This study revealed the presence of $3.3 \%$ of $E$. coli in mixed 
vegetable samples. Here, the mixed vegetables are precut, packed, chilled and sold in retail markets for daily routine cooking purpose. The vegetables were processed by labors working in the shop. Presence of $E$. coli in vegetables indicated faecal contamination due to unhygienic practices of workers while chopping on the uncleaned floor with open air. A number of reports were published on $E$. coli contamination of ready to cook foods ${ }^{2,3,10}$. Presence of Salmonella sp. in fresh poultry has been reported worldwide ${ }^{6,21,8,22}$. This study has also confirmed the presence of Salmonella sp. (3.3\%) in chicken sample. It was found that minimally processed ready to cook chicken samples (leg piece, lollypop, and wings) were contaminated with Salmonella sp. This bacterium occupies the second most foodborne pathogen causing illness. The miscellaneous bacteria of Citrobacter sp. and Serratia sp. constitute a public health hazard which causes diarrhoea and gastroenteritis. Our study revealed that the presence of these species in beef samples (3.3\%). Many studies have reported the presence of Serratia sp. and Citrobacter sp. in different ready to cook food samples ${ }^{5,23,4,24}$. Overall, the poor sanitation in retail outlets and improper handling during storage and transportation increases the microbial contamination of foods and are difficult to control ${ }^{25}$. The occurrence of members of Enterobacteriaceae from ready to cook samples have shown $100 \%$ resistant to Penicillin followed by Gentamycin (72.7\%) Ampicillin (54.5\%). This is in complete agreement with the studies of Kilonzo-Nthenge et al. (2013) ${ }^{26}$ who recorded $89 \%$ resistance to Penicillin and $65.8 \%$ resistance to Ampicillin. It indicated the indiscriminate use of antibiotics as a growth factor in poultry and cattle. Increasing emergence of horizontal gene transfer could disseminate the virulence factor to other strains of same species or different species, might also be the reason for developing multidrug resistance.

\section{CONCLUSION}

The study showed the presence of Enterobacteriaceae in all the collected samples of ready to cook, chilled food products. Personal hygiene, storage temperature maintenance and handling during production could have been the reason which led to the microbial contamination.
The knowledge of thawing and storing chilled food should be made aware to the public. Also, improper cooking and storage temperature lead to foodborne illness. The regulated food laws should be followed by both local retailers and consumers. The emergence of multiple antibiotic resistance by the isolated organisms may be occurred due to horizontal gene transfer which has become a global threat to public health.

\section{ACKNOWLEDGEMENTS}

We would like to thank Bharathidasan University for providing the space to carry out research work. The authors are grateful to Dr. A Murugan, Assistant Professor, V.O.C College, Tuticorin for his assistance with correcting the manuscript.

\section{CONFLICT OF INTEREST}

The authors declare that there is no conflict of interest.

\section{AUTHORS' CONTRIBUTION}

KS designed the work, AJ performed the experiments, generated data and wrote the manuscript. KS read and approved the manuscript.

\section{FUNDING}

None.

\section{ETHICS STATEMENT}

This article does not contain any studies with human participants or animals performed by any of the authors.

\section{DATA AVAILABILITY}

All the data generated during the study are included in this manuscript

\section{REFERENCES}

1. Rahman MA, Rahman AKMA, Islam MA, Alam MM. Antimicrobial Resistance of Escherichia Coli Isolated from Milk, Beef and Chicken Meat in Bangladesh. Bangladesh Journal of Veterinary Medicine. 2017;15(2):141-146. https://doi.org/10.3329/bjvm. v15i2.35525

2. Al-Mutairi MF. The incidence of Enterobacteriaceae causing food poisoning in some meat products. Advance Journal of Food Science and Technology. 2011;3(2):116-121.

3. Abid H, Ali J, Hussain F, ur Rehman Z. Microbiological 
quality evaluation of frozen food available in Peshawar city, Pakistan. Pak J Biochem Mol Biol. 2010;43(1):2932.

4. El-Gendy NM, Ibrahim HA, Al-Shabasy NA, Samaha IA. Enterobacteriaceae in beef products from retail outlets in Alexandria. Alexandria Journal of Veterinary Sciences, 2014;41:80-86. https://doi.org/10.5455/ ajvs.151171

5. Okonko I O, Ogunnusi TA, Ogunjobi AA, et al. Microbial studies on frozen shrimps processed in Ibadan and Lagos, Nigeria. Scientific Research and Essays. 2008;3(11):537-546.

6. Gwida M, Hotzel H, Geue L, Tomaso, H. Occurrence of Enterobacteriaceae in raw meat and in human samples from Egyptian retail sellers. International Scholarly Research Notices, 2014;2014. https://doi. org/10.1155/2014/565671

7. Shekh CS, Deshmukh VV, Waghamare RN, Markandeya NM, Vaidya MS. Isolation of pathogenic Escherichia coli from buffalo meat sold in Parbhani city, Maharashtra, India. Veterinary World. 2013;6(5). https://doi. org/10.5455/vetworld.2013.277-279

8. Gautam RK, Kakatkar AS, Karani MN, Shashidhar R, Bandekar JR. Salmonella in Indian ready-tocook poultry: antibiotic resistance and molecular characterization. Microbiology Research. 2017;8(1). https://doi.org/10.4081/mr.2017.6882

9. Orji MU, Onuigbo HC, Mbata TI. Isolation of Salmonella from poultry droppings and other environmental sources in Awka, Nigeria. Int J Infec. Dis. 2005;9(2):8689. https://doi.org/10.1016/j.ijid.2004.04.016

10. Abd-El-Aziz NA, Moharram YG. Microbiological quality of imported frozen shrimp in Egypt. Annals of Agricultural Sciences. 2016;61(1):35-40. https://doi. org/10.1016/j.aoas.2016.04.002

11. Yadav S, Pimpale V. The changing landscape in demand of RTC food products in Mumbai. IOSR Journal of Business and Management. 2018;36-45.

12. Sundaram N. A market study on key determinants of Ready-to-Eat/cook products with respect to Tier-I cities in Southern India. ZENITH International Journal of Multidisciplinary Research. 2012;2(6):168-180.

13. United States Food and Drug Administration. 2012. Online Bacteriological analytical manual, revised 8th Ed. Arlington.

14. Bergey DH, Breed RS, Murray EGD, Hitchens AP. Manual of determinative bacteriology. 1939;5th Ed.
15. Cappuccino JG, Sherman N. Microbiology: a laboratory manual. 2005;507. 7th Ed. San Francisco: Pearson/ Benjamin Cummings.

16. Wayne PA. Clinical and laboratory standards institute. Performance standards for antimicrobial susceptibility testing. M100S, 28 th Ed. 2018;38(1):19087.

17. Oranusi SU, Obioha TU, Adekeye BT. Investigation on the microbial profile of frozen foods: Fish and Meat. International Journal of Advanced Research in Biological Sciences. 2014;1(2):71-78.

18. Fernandes RTV, Arruda AMVD, Costa MKDO, et al. Physicochemical and microbiological parameters of frozen and chilled chicken meat. Revista Brasileira de Zootecnia. 2016;45(7):417-421. https://doi. org/10.1590/S1806-92902016000700009

19. Mohamed AD, Mohamed RD, Mohamed hm, Abdullah $S A$. Microbiological quality of fresh and frozen ground meat, Alexandria city, Egypt. Saudi J Pathol Microbiol. 2017;2(9):286-290.

20. Chen $\mathrm{CY}$, Chen YH, Lu PL, Lin WR, Chen TC, Lin CY. Proteus mirabilis urinary tract infection and bacteremia: risk factors, clinical presentation, and outcomes. J Microbiol Immunol Infect. 2012;45(3):228236. https://doi.org/10.1016/j.jmii.2011.11.007

21. Sanjee SA, Karim M. Microbiological quality assessment of frozen fish and fish processing materials from Bangladesh. International Journal of Food Science. 2016;2016. https://doi.org/10.1155/2016/8605689

22. Suleiman MA, Wasa AA., Na'ilatu MI, Titus I, Adamu S. Bacteriological Analysis of Chicken Parts of Fresh and Frozen Poultry Chicken Sold in Gombe Metropolis, Nigeria. International Journal of Adulteration. 2016;1(3):58-73.

23. Saad Saad, Edris Abo, A Hassan Mohamed, Sabike Islam. Enterobacteriaceae in slaughtered animals with particular reference to pathogenic strains. Benha Veterinary Medical Journal, 2011;(1):146-152.

24. Shaltout FA. Bacteriological Aspect of Frozen Beef Burger. EC Nutrition. 2017;10:162-172.

25. Vijayan C, Ajaykumar VJ, Bhattacharya A, Bhanurekka V. Detection of enterohaemorrhagic E. coli O157: $\mathrm{H7}$ from beef and chevon sold in and around Puducherry. $J$ Entomol Zool Stud. 2017;5(6):1395-1403.

26. Kilonzo-Nthenge A, Rotich E, Nahashon SN. Evaluation of drug-resistant Enterobacteriaceae in retail poultry and beef. Poultry Science. 2013;92(4):1098-1107. https://doi.org/10.3382/ps.2012-02581 